\title{
PENGGUNAAN RANGKAIAN BOOSTER CONVERTER DAN IC-TP4056 UNTUK LAMPU JALAN MURAH
}

\author{
Ricki Ananda ${ }^{1^{*}, \text { Wiwin Handoko }}{ }^{1}$ \\ ${ }^{1}$ Sistem Komputer, STMIK Royal Kisaran \\ email: *rickianandainterface@gmail.com
}

\begin{abstract}
PJU (Public Street Lighting), is regulated in the regulation of the Minister of Transportation of the Republic of Indonesia Number 27 of 2018, concerning street lighting. In line with the statement of the village minister, development of underdeveloped areas and transmigration (Mendes PDTT), eko putro Sandjojo, said that village funds could be used to make street lamps for villages that do not have street lights. The area of the northern ring road, sub-district of datuk bandar timur in the direction of the port of Teluk Nibung, part of the road has no street lighting at night, plus the road conditions are still classified as red soil. Based on the results of field observations, the team researched making cheap street lamps, by utilizing the basic work system of the joule tief circuit, where the input is 7.4 VDC (in 3.7VDC arranged in series-parallel) with a lamp load of 12 watts multiplied by 4 lamps, with a total load. 48 watts, get the frequency measurement results of $12.30 \mathrm{Khz}$ and Iout $0.14 \mathrm{~A}$, and Vpk-pk $82 \mathrm{~V}$. Charging input is $7.4 \mathrm{VDC}$, the current $19800 \mathrm{mAh}$ in the battery is divided by the maximum current of the solar module 1 watt, which is $160 \mathrm{~mA}$, so the charging time the battery is in the range of 2.1 hours. For the design of the lampposts that were made, using a paralon pipe with a length of $5 \mathrm{~m}$, with a circle diameter of $9 \mathrm{~cm}$, and a second pole connecting $1.5 \mathrm{~m}$ long with a circle diameter of $5 \mathrm{~cm}$.
\end{abstract}

Keywords: Cheap street lights; joule tief series; 1 watt solar panel

\begin{abstract}
Abstrak : PJU (Penerangan Jalan Umum), diatur dalam peraturan mentri perhubungan republik indonesia nomor 27 tahun 2018, tentang alat penerangan jalan. Sejalan dengan pernyataan mentri desa, pembangunan daerah tertinggal dan transmigrasi (Mendes PDTT) eko putro Sandjojo, mengatakan bahwa dana desa bisa digunakan untuk membuat lampu jalan bagi desa yang tidak memiliki lampu jalan. Wilayah jalan lingkar utara, kecamatan datuk bandar timur searah menuju pelabuhan teluk nibung, sebahagian dari jalan tersebut tidak memiliki penerangan jalan dimalam hari, ditambah dengan kondisi jalan yang masih tergolong tanah merah. Berdasarkan hasil pengamatan dilapangan maka tim meneliti membuat lampu jalan murah, dengan memanfaatkan dasar sistem kerja rangkaian joule tief, dimana untuk input 7,4 VDC (in 3,7VDC disusun seri-paralel) dengan beban lampu 12 watt dikalikan 4 lampu, dengan total beban 48 watt, mendapati hasil pengukuran frequensi 12,30 Khz dan Iout 0,14A, dan Vpkpk 82 V. Pengisian input 7,4VDC didapati, arus 19800mAh pada baterai dibagi dengan arus maksimum modul surya 1 watt, yaitu $160 \mathrm{~mA}$, sehingga lama pengisian baterai berada pada rentang waktu 2,1 jam. Untuk rancangan tiang lampu yang dibuat, menggunakan pipa paralon dengan panjang $5 \mathrm{~m}$, dengan diameter lingkaran $9 \mathrm{~cm}$, dan penyambung tiang kedua sepanjang $1,5 \mathrm{~m}$ dengan diameter lingkaran $5 \mathrm{~cm}$.
\end{abstract}

Kata Kunci : Lampu jalan murah; rangkaian joule tief; panel surya 1 watt 
JURTEKSI (Jurnal Teknologi dan Sistem Informasi)

Vol. VII No. 1, Dec 2020, hlm. 9 - 14

DOI: https://doi.org/10.33330/jurteksi.v7i1.886

Available online at http://jurnal.stmikroyal.ac.id/index.php/jurteksi
ISSN 2407-1811 (Print)

ISSN 2550-0201 (Online)

\section{PENDAHULUAN}

Kota Tanjungbalai merupakan salah satu kota yang terletak diprovinsi Sumatera Utara, dengan luas wilayah $60,52 \mathrm{~km}^{2}$, jumlah penduduk saat ini 167012 jiwa [1]. Terfokusnya pemko Tanjungbalai dengan pembangunan jalan lingkar utara, melupakan pemko untuk meratakan fasilitas jalan tersebut dengan akses lampu jalan, padahal masih banyak pemukiman warga yang berada disekitar jalan lingkar tersebut, Untuk membangun satu unit lampu jalan memakai panel surya dengan menggunakan indikator dari jalan lokal primer, harus memiliki minimal kemerataan $0,10 \mathrm{~g}$ dengan rata-rata lux 2$5 \mathrm{E}$, dan indikator kuat pencahayaan 25lux, dengan batas silau $15 \%$ dan total pembiayaan pembuatan satu buah lampu jalan pemko harus menyiapkan dana sebesar Rp. 9.291.600. Total panjang jalan lingkar 7 kilometer, dengan jarak titik tiang ketiang lainnya 35 meter, maka pemko harus menyiapkan setidaknya 200 titik lampu jalan dengan total anggaran sebesar Rp. 1.858.320.000 [2].

Ada beberapa penelitian yang mengarah state of the art, tentang penelitian terdahulu, mendapati bahwa penggunaan rangkaian joule tief atau booster converter difungsikan untuk menaikan tegangan keluaran pada lampu [3]. Penelitian sel volta pada air laut dengan tegangan jepit $0,8 \mathrm{~V}$ mampu mengaktifkan dioda led dengan konfigurasi rangkaian serial. hasilnya power transfer maksimum dari sirkuit joule thief sangat efektif sebagai pemasok daya beban 60 led [4].

Didasari dari kondisi jalan lingkar utara yang masih minim PJU (penerangan jalan umum), dan state of the art pada penelitian terdahulu, maka sistem yang akan dibuat merancang sebuah lampu jalan murah yang nantinya bisa diaplikasikan untuk penerangan jalan diwilayah jalan lingkar utara, ataupun bisa diaplikasikan ditempat lainnya, dengan mengabaikan beberapa faktor pendukung seperti kemerataan lux, pencahayaan dan batas silau yang tidak begitu besar serta bahan pembentuk tiang listrik dengan memanfaatkan pipa paralon untuk meminimlisir harga.

\section{METODE}

Metode penelitian yang digunakan dalam penelitian ini, menggunakan metode kuantitafi, dimana dalam perancangan lampu jalan murah, harus lebih murah jika dibandingkan dengan biaya pembuatan lampu jalan yang ada pada umumnya.

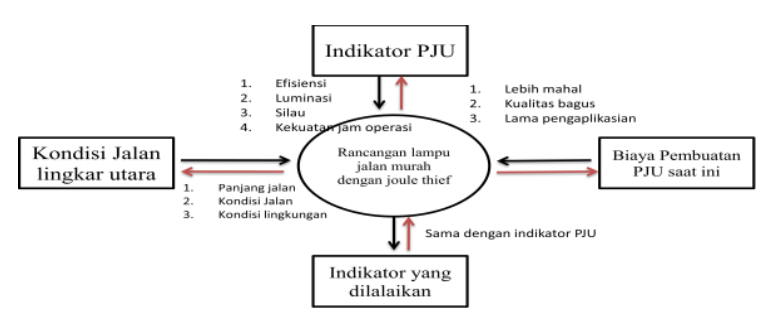

Gambar 1. Data Flow Diagram Penelitia

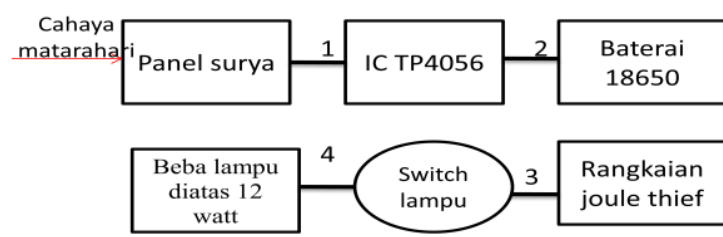

Gambar 2. Blok diagram rancangan tiang lampu

Tujuan dalam penelitian ini untuk menciptakan lampu jalan murah dengan memanfaatkan rangkaian joule thief bagi penerangan diwilayah jalan lingkar utara kota Tanjungbalai. 
DOI: https://doi.org/10.33330/jurteksi.v7i1.886

Available online at http://jurnal.stmikroyal.ac.id/index.php/jurteksi

\section{Indikator PJU (Penerangan Jalan Umum)}

Perancangan lampu jalan harus mempertimbangkan beberapa indikator, diantaranya, jenis lampu yang digunakan memiliki efisiensi 60-70 watt dengan daya 18-20 watt [5]. Adapun indikator minimal yang dijadikan tolak ukur, ditunjukan pada tabel 1.

Tabel 1. Indikator berdasarkan SNI

\begin{tabular}{|c|c|c|c|c|}
\hline 1 & Daya & $\begin{array}{l}\text { Lum } \\
\text { en/w } \\
\text { att }\end{array}$ & umur & $\begin{array}{l}\text { Indek perlindungan } \\
\text { (IP) }\end{array}$ \\
\hline Trotoar & $18-20$ & $\begin{array}{l}60- \\
70\end{array}$ & $\begin{array}{l}8 \mathrm{k}- \\
10 \mathrm{k} \\
\text { jam }\end{array}$ & $\begin{array}{lr}1 \text { (tahan } & \text { terhadap } \\
\text { sentuhan } & \text { dn } \\
\text { masuknya benda } & \text { padat }<50 \mathrm{~mm})\end{array}$ \\
\hline $\begin{array}{l}\text { Kemer } \\
\text { ataan E } \\
\text { (lux) }\end{array}$ & $\begin{array}{c}\text { Kemer } \\
\text { ataan } \\
\text { lumini } \\
\text { nasi } \\
\end{array}$ & $\begin{array}{l}\text { Batas } \\
\text { an } \\
\text { silau }\end{array}$ & $\begin{array}{l}\text { Kuat } \\
\text { penc } \\
\text { ahay } \\
\text { aan }\end{array}$ & $\begin{array}{l}\text { Tingkat kegiatan } \\
\text { lingkungan lokasi }\end{array}$ \\
\hline 0,10 & 0,50 & 20 & 5 & rendah \\
\hline
\end{tabular}

\section{Panel surya 1 watt}

Panel surya bekerja mengubah energi cahaya matahari menjadi energi listrik. Panel Surya adalah alat yang terdiri dari sel surya, baterai yang mengubah cahaya menjadi listrik. Panel surya menghasilkan arus listrik searah atau DC [6][7]. Jenis modul surya yang digunakan memiliki daya 1 watt, tegangan $6 \mathrm{v}$, Imax $=0,2 \mathrm{~A}$ dan ukuran $11 \times 6 \times 0.25 \mathrm{~cm}$.

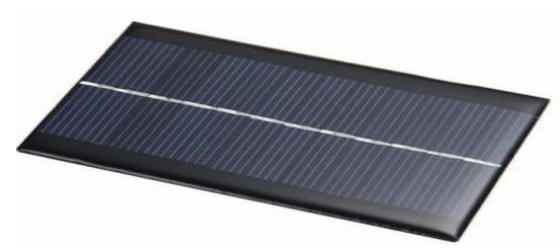

Gambar 3. Modul surya 1 waat

\section{Rangkaian joule thief}

Untuk rangkaian joule thief yang digunakan ditunjukan pada gambar 4 .

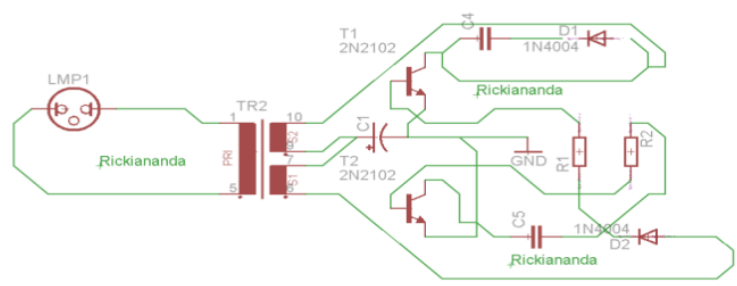

Gambar 4. scematik joule thief

Pada gambar 4, trafo yang digunakan merupakan jenis trafo yang diambil dari charger bekas handphone oppo, dan untuk komponen lainnya menggunakan komponen elektronika biasa, selain itu untuk SCR yang digunakan menggunakan tip 41 [8].

\section{IC TP4056}

TP4056 adalah pengisi linear arus konstan atau tegangan penuh pada baterai lithium dengan sel tunggal. tegangan keluaran sebesar $4,2 \mathrm{~V}$ dan arus muatan dapat program secara eksternal dengan resistor tunggal [9].

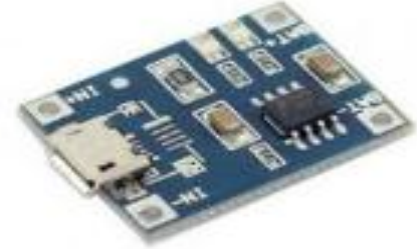

Gambar 5. Modul IC TP4056

\section{Baterai 18650}

Jenis baterai yang digunakan merupakan baterai 18650, merk ultrafire dan memiliki tegangan kerja 3,7VDC yang nantinya akan diserikan, sehingga mendapat tegangan keluaran sebesar 7.4VDc. Selain itu, arus berada pada nilai 19800mAh [10].

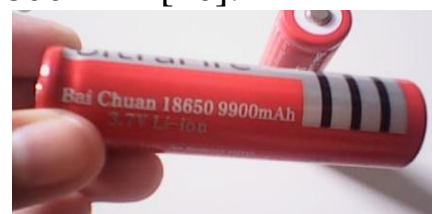

Gambar 6. Baterai 18650 jenis ultrafire 
JURTEKSI (Jurnal Teknologi dan Sistem Informasi)

Vol. VII No. 1, Dec 2020, hlm. 9 - 14

DOI: https://doi.org/10.33330/jurteksi.v7i1.886

Available online at http://jurnal.stmikroyal.ac.id/index.php/jurteksi
ISSN 2407-1811 (Print)

ISSN 2550-0201 (Online)

\section{Ukuran tiang dengan paralon}

Rancangan tiang lampu murah yang akan dibuat, menggunakan bahan dari pipa paralon. Adapun spesifikasi dari bahan pembentuk tiang, ditunjukan pada tabel 2.

Tabel 2. Spesifikasi PVC yang dipakai

\begin{tabular}{lllll}
\hline Tiang & Ukuran & Tebal & Tipis & Panjang \\
\hline Tiang 1 & $89 \mathrm{~mm}$ & AW3 & C3 & $3,5 \mathrm{~m}$ \\
\hline Tiang 2 & $32 \mathrm{~mm}$ & AW1 & C1 & $2,5 \mathrm{~m}$ \\
\hline
\end{tabular}

Sementara untuk desain tiang lampu yang akan dibuat, ditunjukan pada gambar 7.

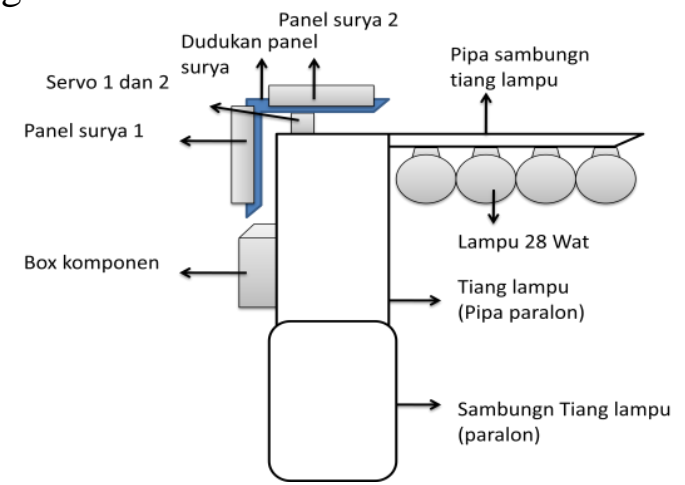

Gambar 7. Contoh desain tampilan tiang lampu dengan PVC

\section{HASIL DAN PEMBAHASAN}

\section{Rangkaian joule thief}

Pada gambar 4 menunjukan scematik rangkaian pada layout simbol, sementara pada gambar 8 menunjukan layout jadi rangkaian pada print circuit board (PCB).

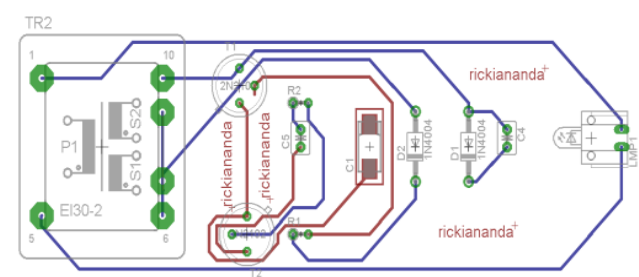

Gambar 8. Sircuit layout joule thief pada pcb
Gambar 8, menunjukan ada beberapa komponen elektronika yang digunakan, seperti ditunjukan pada tabel 3.

Tabel 3. Komponen pembentuk joule tief

\begin{tabular}{ccc}
\hline Komponen & Jumlah & Nilai \\
\hline Trafo & 1 & Exs. adaptor hp \\
\hline Kapasitor & C1 x 2 & $100 \mathrm{nF}$ \\
& C2 $\times 1$ & $1000 \mathrm{uf}$ \\
\hline Resistor & R $1 \times 2$ & $100 \mathrm{ohm}$ \\
\hline Dioda & D1 x 2 & IN4004 \\
\hline Transistor & TR x 2 & TIP 41/3003 \\
\hline
\end{tabular}

\section{Pengkabelan modul surya 1 watt dengan ic tp 4056}

Adapun sirkuit 2 modul surya 1 watt yang dihubungkan secara paralel ke IC TP 4056 bertujuan untuk mempercepat pengisian baterai 7,4VDC untuk mensupply beban dari rangkaian joule tief.

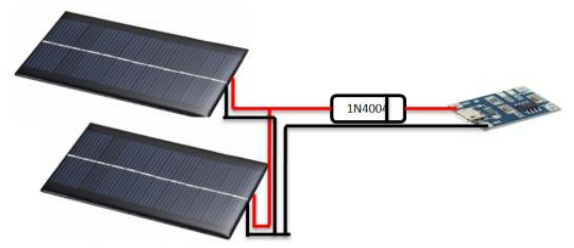

Gambar 9. Sirkuit 2 modul surya dengan Modul IC TP4056

\section{Pemasangan rangkaian pada tiang lampu jalan}

Pemasangn beban lampu, box komponen serta panel surya di tiang lampu jalan yang terbuat dari paralon, ditunjukan pada gambar 10.

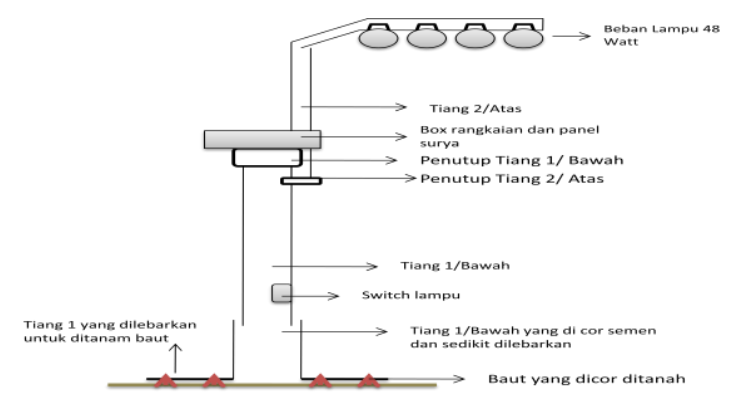

Gambar 10. Pemasangan rangkaian pada tiang lampu jalan murah 
JURTEKSI (Jurnal Teknologi dan Sistem Informasi)

Vol. VII No. 1, Dec 2020, hlm. 9 - 14

DOI: https://doi.org/10.33330/jurteksi.v7i1.886

Available online at http://jurnal.stmikroyal.ac.id/index.php/jurteksi
ISSN 2407-1811 (Print)

ISSN 2550-0201 (Online)

\section{Pengukuran tegangan keluaran Panel Surya}

hasil pengujian modul surya 1 watt yang dilakukan, dibawah matahari, dan tidak dibawah matahari, ditunjukan pada tabel 4.

Tabel 4. Hasil pengukuran panel surya pada saat disinari matahari

\begin{tabular}{cccc}
\multicolumn{4}{c}{ surya pada saat disinari matahari } \\
\hline $\begin{array}{c}\text { Waktu } \\
\text { Pengujian }\end{array}$ & Tegangan & Arus & Beban \\
\hline $\begin{array}{c}\text { 09.00 (Tidak } \\
\text { dibawah } \\
\text { matahari) }\end{array}$ & 5.8 VDC & $0,02 \mathrm{~A}$ & $100 \Omega$ \\
\hline $\begin{array}{c}\text { 13.00 (Dibawah } \\
\text { matahari) }\end{array}$ & $7.0 \mathrm{VDC}$ & $0,10 \mathrm{~A}$ & $100 \Omega$ \\
\hline
\end{tabular}

Sementara pada gambar 11, menunjukan dokumentasi pengujian panel surya 1 watt dengan voltmeter digital.

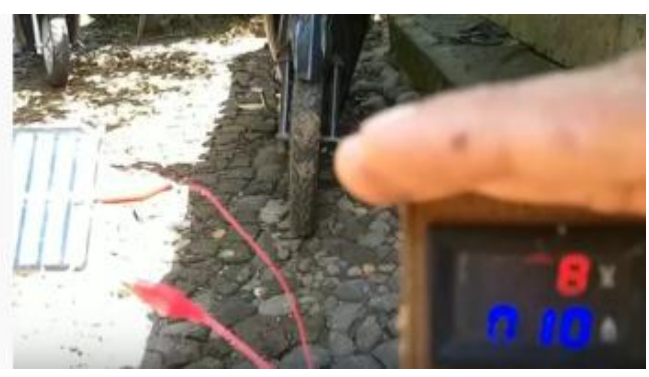

Gambar 11. Pengukuran modul surya dengan voltmeter

\section{Pengukuran Keluaran IC TP4056 dan baterai 7,4 VDC dan beban}

Hasil pengukuran keluaran ic pada saat beban diaktifkan dengan supply dari baterai 7.4 VDC ditunjukan pada tabel 5.

Tabel 5. Hasil pengukuran keluaran IC TP4056 dan baterai 7.4 VDC

\begin{tabular}{ccc}
\hline $\mathbf{V}_{\text {Baterai }}$ & Beban & $\begin{array}{c}\text { Kondisi } \\
\text { Lampu }\end{array}$ \\
\cline { 1 - 1 } 3.7 VDC & Pijar & Terang \\
\cline { 1 - 1 } 7.62 VDC & 1.5 VDC, 0,3 A & Terang \\
\hline
\end{tabular}

\section{Pengukuran tegangan keluaran rangkaian}

Pengukuran tegangan untuk beban lampu 48 watt, menggunakan multitester, dengan kalibrasi yang berbeda beda untuk membaca input dan output, seperti ditunjukan pada tabel 6 .

Tabel 6. Hasil pengukuran beban lampu

\begin{tabular}{cccc}
\hline Kalibrasi & In & Out & Beban \\
\hline 10 VDC & 7.4 VDC & - & \multirow{2}{*}{$48 \mathrm{~W}$} \\
\cline { 1 - 2 } 250 VDC & - & 188 VDC & \\
\cline { 1 - 2 } & & \\
& & \\
& & \\
& & \\
& &
\end{tabular}

Gambar 13 Rangkaian penyearah joule thief diparalelkan

Pada gambar 15 menampilkan hasil pengujian keseluruhan lampu dan prototype tiang lampu yang dirancang. Beban lampu 48 watt mampu menyala dengan memanfaatkan input dari baterai 7.4 VDC dan modul surya 1 watt sebanyak dua unit, sehingga mampu mengisi 4 baterai 3.7VDC selama 2.1 jam, dengan rentang waktu nyala maksimal 5 sampai 6 jam.

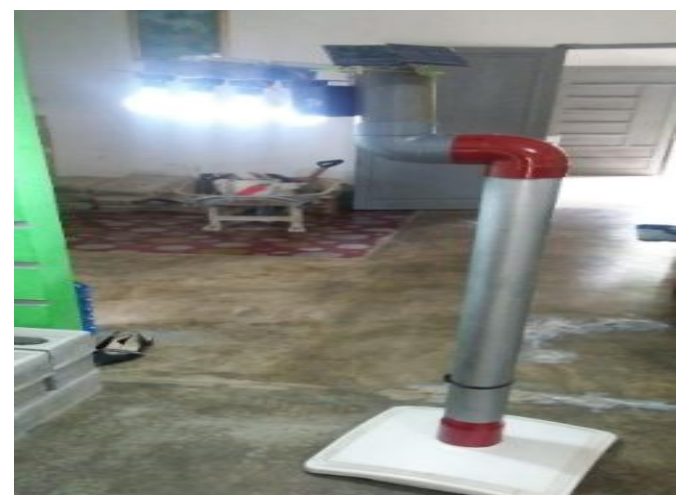

Gambar 15. Rancangan lampu jalan dengan beban lampu 48 watt 
DOI: https://doi.org/10.33330/jurteksi.v7i1.886

Available online at http://jurnal.stmikroyal.ac.id/index.php/jurteksi

\section{SIMPULAN}

Power yang diberikan oleh baterai littium 18650 yang dihubungkan secara seri-paralel kerangkian joule thief yang penyearh nya diparalelkan mampu meningkatkan tegangan 7,4VDC menjadi $188 \mathrm{~V}$ untuk menyalakan beban 48 lampu yang terhubung secara paralel.

Sementara untuk rancangan tiang lampu yang dibuat, menggunakan pipa paralon dengan panjang $5 \mathrm{~m}$, dengan diameter lingkaran $9 \mathrm{~cm}$, dan penyambung tiang kedua sepanjang 1,5 $\mathrm{m}$ dengan diameter lingkaran $5 \mathrm{~cm}$ dan pengisian input 7,4VDC didapati, arus 19800mAh pada baterai dibagi dengan arus maksimum modul surya 1 watt, yaitu $160 \mathrm{~mA}$, sehingga lama pengisian baterai berada pada rentang waktu 2,1 jam.

\section{UCAPAN TERIMA KASIH}

Ucapan terimakasih kepada DRPM Deputi Bidang Penguatan Riset Dan Pengembangan Kementerian Riset Dan Teknologi/Badan Riset Dan Inovasi Nasional Sesuai dengan Kontrak Penelitian Tahun Anggaran 2020.

\section{DAFTAR PUSTAKA}

[1] R.-J. kota Tanjungbalai, "Bab 4 profil kota tanjungbalai," tanjungbalai, 2001. [Online].

[2] Permenkes, "Perancanaan dan Analisis Pembiayaan Penerangan Jalan Umum (PJU)," VOL $1 O$ NO 2. 2018, vol. 10, no. 2, pp. 1-15, 2018.

[3] F. Trisnawati, A. Chaniago, and P. Prasetyawan, "Prototipe Lampu Belajar Menggunakan Mini Inverter Berbasis Konservasi Energi," vol. 1, no. October 2018, pp. 86-90, 2018.
[4] A. Mujadin and S. Rahmatia, "Joule Thief Sebagai Boost Converter Daya LED Menggunakan Sel Volta Berbasis Air Laut," J. Al-AZHAR Indones. SERI SAINS DAN Teknol., vol. 4, no. 2, p. 52, 2018, doi: 10.36722/sst.v4i2.254.

[5] A. Effendi; and M. Aldifian, "Perencanaan Penerangan Jalan Umum Jalan Lingkar Utara Kota Solok," Jurnal Teknik Elektro ITP, vol. 1 No.2, no. Januari 2012. p. 9 , 2012.

[6] Z. Iqtimal and I. Devi, "Aplikasi Sistem Tenaga Surya Sebagai Sumber Tenaga Listrik Pompa Air," J. Karya Ilm. Tek. Elektro, vol. 3, no. 1, pp. 1-8, 2018.

[7] Ananda, Ricki, "Control Of A Robot Car With Two Commands Via Hc05 Ricki," vol. 4509, no. 1, pp. 7176, 2020.

[8] S. Hasan, R. Ananda, A. H. Rambe, and Suherman, "Power wireless transferbased on a royeroscillator," IOP Conf. Ser. Mater. Sci. Eng., vol. 420, no. 1, 2018, doi: 10.1088/1757899X/420/1/012050.

[9] NanJing Top Power ASIC Corp, "TP4056 1A Standalone Linear Lilon Battery Charger with Thermal Regulation in SOP-8," Data Sheet, vol. Nanjing to, p. 3, 2019.

[10]M. Amin and R. Ananda, "Application Solar Cells On Helmes As A Handphone Battery Charger," proceeding Int. confrence Soc. Sci. Inf. Technol., vol. 4509, no. 1, pp. 53-60, 2020. 